\section{Megaprimer Mutagenesis Using Very Long Primers}

BioTechniques 34:52-56 (January 2003)

It is well known that some genetic mutations have a critical impact on protein structure and function. To study the effects of these mutations, site-directed mutagenesis allows the introduction of a defined substitution of specific residues. For the past few years, numerous PCR-based methods have been employed for achieving site-directed mutagenesis. Among these methods, megaprimer PCR has been widely employed because of its simplicity and low cost (5).

In brief, megaprimer PCR utilizes three PCR primers in two rounds of PCR amplification. In the first round of PCR amplification, the external forward primers $(\mathrm{F})$ and internal mutant reverse primers $(\mathrm{M})$ were responsible for inducing a specific mutation into the PCR product. In the second round of PCR amplification, the PCR products from the first round of PCR amplification act as the megaprimers, together with the external reverse primers (R), and the full length of the target sequence is amplified with the desired mutation. Based on this principle, numerous different approaches have emerged to achieve accurate induction of mutations $(2,3,6)$. These studies relied on megaprimers that were around $300 \mathrm{bp}$. Other studies have indicated that, for megaprimers longer than 300 $\mathrm{bp}$, an excess amount of template is required to produce the desired PCR product yield (1).

However, in our hands, the use of these methods $(1,2,6)$ with a much longer megaprimer ( $800 \mathrm{bp}$ in length) resulted in a very low percentage of clones that carried a desired mutation. Here we report the development of a simple and reliable adapted method for longer megaprimer site-directed mutagenesis.

Our new site-directed mutagenesis strategy has been applied successfully to generate several mutants of the tumor suppressor gene, $p 53$, and mutants in $\mathrm{K}$ ras. The method successfully generated several "hot spot" mutations including the $p 53$ codon 282 mutation. To illus- trate the method, only the codon 282 results will be presented here. Figure 1 outlines the overall procedure. The method consists of two PCR amplifications. In the first round of PCR, the reaction was carried out in a total volume of $50 \mu \mathrm{L}$. The reaction consisted of $2.5 \mathrm{U}$ PfuTurbo ${ }^{\circledR}$ DNA polymerase (Stratagene, La Jolla, CA, USA), PCR buffer [20 mM Tris- $\mathrm{HCl}, 2 \mathrm{mM} \mathrm{MgSO}_{4}, 10$ $\mathrm{mM} \mathrm{KCl}, 10 \mathrm{mM}\left(\mathrm{NH}_{4}\right)_{2} \mathrm{SO}_{4}, 0.1 \%$ Triton ${ }^{\circledR} \mathrm{X}-100$, and $\left.0.1 \% \mathrm{BSA}\right], 320 \mathrm{pg} / \mu \mathrm{L}$ wild-type $p 53$ inserted in pcDNA vector (Promega, Madison, WI, USA), $0.4 \mathrm{mM}$ dNTP, $0.2 \mathrm{mM} F$ primer (5'-GCCTAAGCTTTCACTGCCATGGAGGAG-3') and $0.2 \mathrm{mM} \mathrm{M}$ primer (5'-CTTCCTCTGTGCGCCAGTCTCTCC-3') (Figure 1). First-round PCR was performed under the following conditions: $95^{\circ} \mathrm{C}$ for 5 min of initial denaturation, followed by 20 cycles of template denaturation at $94^{\circ} \mathrm{C}$ for $1 \mathrm{~min}$, primer annealing at $55^{\circ} \mathrm{C}$ for $1 \mathrm{~min}$, and primer extension at $72^{\circ} \mathrm{C}$ for $1.5 \mathrm{~min}$. The reaction was finished with final extension at $72^{\circ} \mathrm{C}$ for $10 \mathrm{~min}$.

An important modification of previous methods is that, after the first round of PCR amplification, only primers were removed by using PCR purifica- tion (Qiagen, Valencia, CA, USA). In the second round of PCR amplification, the reaction was also carried out in 50 $\mu \mathrm{L}$ reaction volume. It consisted of 10 $\mu \mathrm{L}$ "carryover" first-round PCR product, which was approximately $6 \mathrm{ng} / \mu \mathrm{L}$, 2.5 U PfuTurbo DNA polymerase, PCR buffer, $0.4 \mathrm{mM}$ dNTP, and $2 \mathrm{mM}$ $\mathrm{MgCl}_{2}$. Because of the low full-length template concentration, the mixture was initially heated at $95^{\circ} \mathrm{C}$ (for $5 \mathrm{~min}$ for initial denaturation) and followed by five cycles of asymmetric PCR, where the templates were denatured at $95^{\circ} \mathrm{C}$ for $1 \mathrm{~min}$ and only megaprimer annealed and extended at $72^{\circ} \mathrm{C}$ for $3 \mathrm{~min}$. According to two previous studies $(3,7)$, this asymmetric PCR will increase the product yield when limited templates were available at the start of the PCR cycle. At the end of asymmetric PCR, R primer (5'-GAAGTCTAGAATGTCAGTCTGAGTCAGG-3') (Figure 1) was added into the reaction mixture to 0.2 $\mathrm{mM}$. The full length of $p 53$ mutant cDNA was amplified by 20 PCR cycles, as described for the first-round PCR. Finally, the PCR products were purified and digested with HindIII and $X b a \mathrm{I}$ restriction enzymes (New England Biolabs, Beverly, MA, USA) and cloned

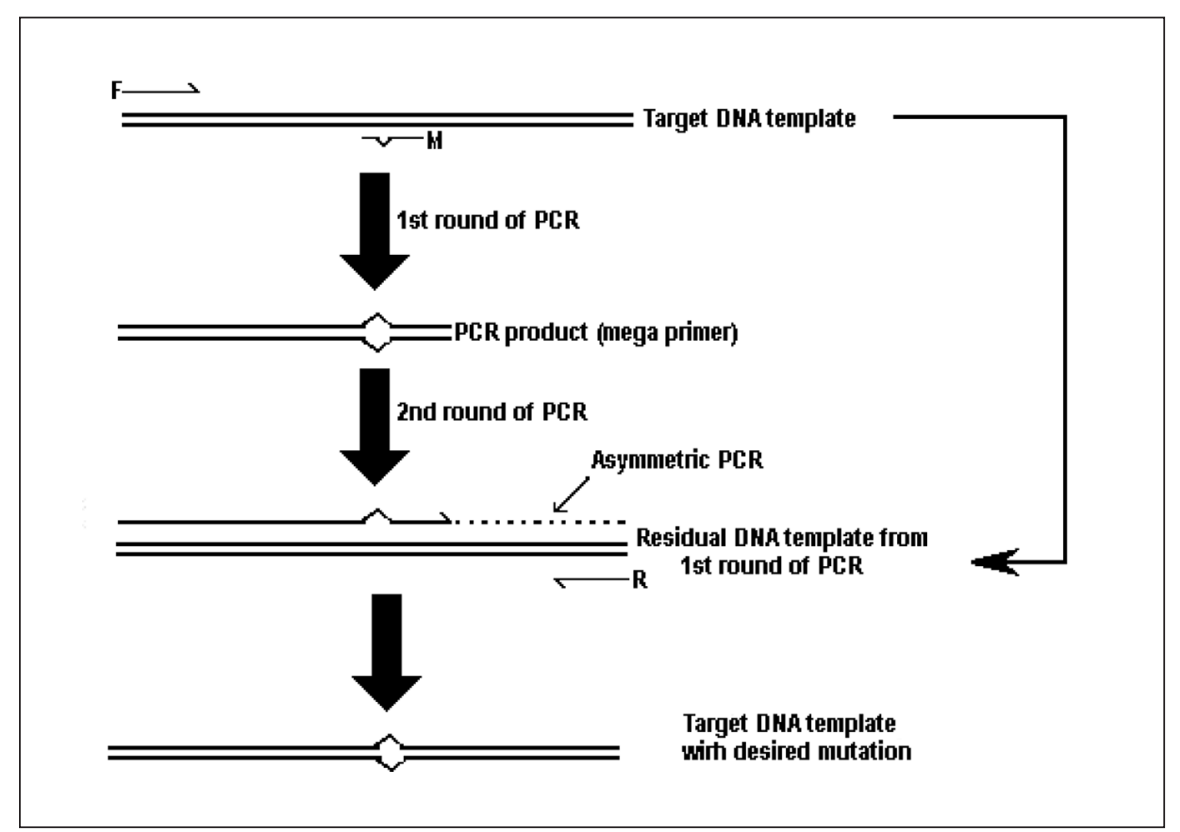

Figure 1. Schematic representation of the mutagenesis method. The megaprimer product from the first round of PCR was amplified by using external forward primer (F) and internal reverse mutant primer (M). After the first round of PCR, the PCR product and template were purified and subjected to a second round of PCR. Because of the low template concentration, five cycles of asymmetric PCR were performed to extend the megaprimer. The final mutant PCR product could be obtained by adding the external reverse primer $(\mathrm{R})$ 


\begin{tabular}{|c|c|c|c|c|}
\hline Experiment No. & $\begin{array}{l}\text { Template in } \\
\text { First-Round } \\
\text { PCR (ng) }\end{array}$ & $\begin{array}{c}\text { Template in } \\
\text { Second-Round } \\
\text { PCR }\end{array}$ & $\begin{array}{c}\mathrm{MgCl}_{2} \text { in } \\
\text { Second-Round } \\
\text { PCR (mM) }\end{array}$ & Result \\
\hline 1 & 16 & $1 \mu \mathrm{g}$ & 2 & $25 \%(3 / 12)$ \\
\hline 2 & 16 & $16 \mathrm{ng}$ & 4 & $75 \%(9 / 12)$ \\
\hline 3 & 16 & $0 \mathrm{ng}$ & 4 & $100 \%(12 / 12)$ \\
\hline
\end{tabular}

into the pIND vector (Invitrogen, Carlsbad, CA, USA) before sequence analysis by BigDye ${ }^{\mathrm{TM}}$ Terminator chemistry at the Australian Genome Research Facility (Brisbane, Queensland, Australia).

From the first round of PCR, $20 \mu \mathrm{L}$ PCR products were analyzed by agarose gel electrophoresis (Figure 2). The result indicates that $16 \mathrm{ng}$ starting plasmid template in the first round of reaction resulted in the optimum template concentration for the successful amplification of an 800-bp megaprimer product. A similar result was obtained in three repeat experiments. More than $16 \mathrm{ng}$ template did not produce a substantial increase in product yield. Analysis of the second-round PCR product by agarose gel electrophoresis showed that additional $\mathrm{MgCl}_{2}$ concentration was crucial for the final $1.2-\mathrm{kb}$ PCR product (Figure 3). The experiment has been repeated four times; all the results were similar and indicated that the optimized minimum $\mathrm{MgCl}_{2}$ concentration was $4 \mathrm{mM}$.

To examine the effect of wild-type

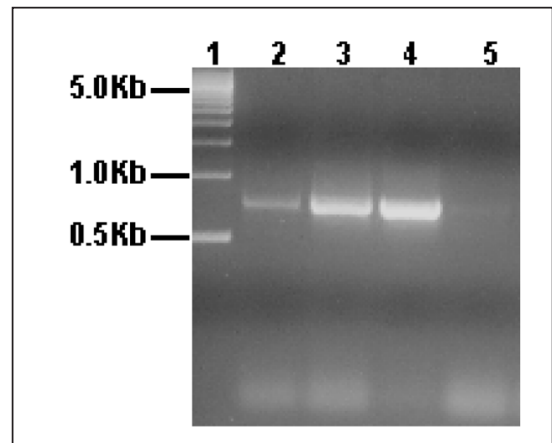

Figure 2. Effect of template concentration in the first round of PCR amplification. Lane 1, 600 ng DMW 500 DNA ladder (GeneWorks, Adelaide, Australia). Lane 2, $20 \mu \mathrm{L}$ PCR product using $8 \mathrm{ng}$ template. Lane $3,20 \mu \mathrm{L}$ PCR products using 16 ng template. Lane 4, $20 \mu \mathrm{L}$ PCR product using $32 \mathrm{ng}$ template. Lane 5, water control where no template was added. The size of the PCR product was $0.8 \mathrm{~kb}$. template concentration, three different set of experiments were performed (Table 1). After transformation of the pIND vector into DH5 $\alpha$ bacteria cells, $10 \%$ of the transformed culture was cultured on the LB agar plate supplemented with ampicillin. Twelve colonies were observed on the plate from this new method, 13 colonies were observed on the plate from the modified new method, where an additional $16 \mathrm{ng}$ wild-type template were added to the second round of reaction, and, finally, 12 colonies were observed on the plate from the conventional method $(1,6)$. Twelve colonies were picked up from each plate for sequence analysis (Table 1). Chi-squared analyses showed that this difference in yield of mutant clones was significant at the $5 \%$ level. This method has also been applied routinely to successfully generate the $p 53$ codon $175,245,248$, and 273 mutants with $100 \%$ efficiency of induction (not shown).

Most of the published methods on site-directed mutagenesis have been

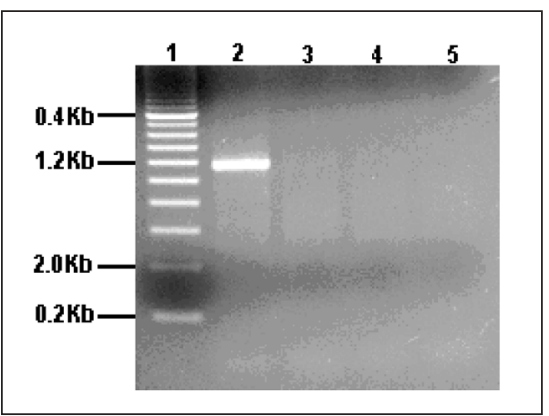

Figure 3. Effect of $\mathrm{MgCl}_{2}$ in the second round of PCR amplification. Lane 1, DMW 200 DNA ladder (GeneWorks). Lane 2, $20 \mu \mathrm{L}$ PCR product using $4 \mathrm{mM} \mathrm{MgCl}_{2}$. Lane 3, $20 \mu \mathrm{L}$ PCR product using $3 \mathrm{mM} \mathrm{MgCl}_{2}$. Lane 4, $20 \mu \mathrm{L}$ PCR product using $2 \mathrm{mM} \mathrm{MgCl}_{2}$. Lane 5, $20 \mu \mathrm{L}$ PCR product using $4 \mathrm{mM} \mathrm{MgCl}$, but no reverse primer has been added (water control). The PCR product was $1.2 \mathrm{~kb}$, which is the full length of the $p 53$ gene. based on megaprimers that were approximately $300 \mathrm{bp}$ in length. A previous study (1) pointed out that megaprimers greater than $300 \mathrm{bp}$ required higher template concentration to favor the binding of the megaprimer to template. However, the latter study did not carry out full sequencing to determine the presence or absence of secondary mutations or the frequency of wild-type products. By contrast, the main feature of our method is to limit the amount of the wild-type template available during the amplification. This was done because higher wild-type template concentration was associated with a lower percentage of mutant clones generated after PCR amplification. Furthermore, the megaprimer to wild-type template annealing problem was overcome by the use of additional $\mathrm{MgCl}_{2}$ in the second round of PCR amplification. However, it should be noted that an excess amount of the $\mathrm{MgCl}_{2}$ would increase the risk of nonspecific amplification in PCR.

A possible reason for the lower percentage yield of mutant clones using the conventional method may be that, during the annealing step of PCR, the R primers were competing to bind to both wild-type template and PCR mutant template. Binding of $\mathrm{R}$ primer to wildtype template would decrease the percentage of mutant PCR product generated at the end of the reaction. From this point of view, if the amount of wild-type templates were limited, then the chance for R primer-wild-type template binding should also decrease. Our method achieves low wild-type template concentration by using the residual wild-type template from the first round of PCR amplification. Because of the limited of amount of template at the start of the second round of PCR amplification, the asymmetric PCR was performed to increase the mutant template concentration for $\mathrm{R}$ primer to bind.

A higher $\mathrm{MgCl}_{2}$ concentration was required to facilitate the binding between megaprimer and template (Figure 3). The same requirement for elevated $\mathrm{MgCl}_{2}$ was also observed for the $\mathrm{K}$-ras and all other p53 PCR site-directed mutagenesis (not shown).

From this study, we conclude that utilizing carryover template and higher $\mathrm{MgCl}_{2}$ concentration is the crucial factor for the introduction of a defined mu- 
tation into a target protein for megaprimer that is longer than $300 \mathrm{bp}$. To our knowledge, this is the first work with very high efficiency (approaching $100 \%$ ) for site-directed mutagenesis PCR using megaprimer that is $800 \mathrm{bp}$ in length. This method will be of particular utility for producing the mutations in long target template with long megaprimer.

\section{REFERENCES}

1.Barik, S. and M.S. Galinski. 1991 "Megaprimer" method of PCR: increased template concentration improves yield. BioTechniques 10:489-490.

2.Colosimo, A., Z. Xu, G. Novelli, B. Dallapiccola, and D.C. Gruenert. 1999. Simple version of "megaprimer" PCR for site-directed mutagenesis. BioTechniques 26:870-873.

3.Datta, A.K. 1995. Efficient amplification using "megaprimer" by asymmetric polymerase chain reaction. Nucleic Acids Res. 23:45304531.

4.Giebel, L.B. and R.A. Spritz. 1990. Site-directed mutagenesis using a double-stranded DNA fragment as a PCR primer. Nucleic Acids Res. 25:4947.

5.Ling, M.M. and B.H. Robinson. 1997. Approaches to DNA mutagenesis: an overview. Anal. Biochem. 254:157-178.

6.Sarkar, G. and S.S. Sommer. 1990. The "megaprimer" method of site-directed mutagenesis. BioTechniques 8:404-407.

7.Smith, A.M. and K.P. Klugman. "Megaprimer" method of PCR-based mutagenesis: the concentration of megaprimer is a critical factor. BioTechniques 22:438-442.

We are indebted to Dr. Melissa Brown (The Department of Biochemistry and Molecular Biology, The University of Queensland) for the kind gift of wild-type p53 clones. Address correspondence to A/Prof. Ross Barnard, The Department of Biochemistry and Molecular Biology, The School of Molecular and Microbial Science, The University of Queensland, Brisbane, Queensland 4072, Australia. e-mail: rossbarnard@mailbox.uq.edu.au

Received 15 July 2002; accepted 16 October 2002.

R. Lai, A. Bekessy, C.C. Chen, T. Walsh ${ }^{1}$, and R. Barnard The University of Queensland

${ }^{1}$ The Queensland University of Technology

Brisbane, Queensland, Australia

\section{Reverse-Polarity PAGE for Examining DNA Binding Domain Phosphorylation}

BioTechniques 34:56-59 (January 2003)

As interest in the signaling pathways impacting nuclear protein function increases, more investigators are examining transcription factor phosphorylation. Most phosphorylation events within proteins can be mapped using a variety of 1D or 2-D phosphopeptide mapping approaches $(2-4,6,8)$. However, these conventional approaches may not be optimal for examining phosphorylation events that occur within the DNA binding domains of transcription factors. Since DNA binding domains typically contain a high proportion of basic residues and most electrophoretic phosphopeptide mapping techniques separate molecules based on size and net negative charge, peptides containing a basic DNA binding domain usually migrate through conventional gels very poorly, if at all. An alternative method for examining the phosphorylation state of basic DNA binding domains would be significant, since post-translational modification of these domains has the potential of altering the interaction of transcription factors with target DNA and contributing to the regulation of the function of these proteins in vivo $(5,7,9)$.

Here we describe reverse-polarity PAGE, a phosphopeptide mapping approach designed for examining phosphorylation events within the basic DNA binding domains of transcription factors. The principle of this technique is to perform PAGE with the anode and cathode leads reversed, thus allowing only peptides with a net positive charge to migrate through the gel. This approach addresses problems inherent to the detection of highly basic peptides with conventional PAGE by focusing on the resolution of positively charged peptides, rather than all peptides, from a protein digest. Since relatively few phosphopeptides from a typical protein digest are likely to have a net positive charge, the number of peptides detected by reverse-polarity PAGE is small and data interpretation is simplified.
Vertical slab gels $(0.75 \times 18 \times 16 \mathrm{~cm})$ for the Hoefer SE 600 electrophoresis apparatus are used for reverse-polarity PAGE. The resolving gel $(19 \%$ acrylamide, $0.018 \%$ bis-acrylamide, $0.1 \%$ ammonium persulfate, and $10 \mu \mathrm{L}$ TEMED) is prepared in $100 \mathrm{mM}$ sodium phosphate buffer, $\mathrm{pH}$ 6.0, cast leaving approximately two inches of space for the stacking gel and overlaid with butanol until polymerization occurs. The butanol is removed with several washes of deionized water and $10 \mathrm{~mL}$ stacking gel (3\% acrylamide, $0.125 \%$ bis-acylamide, $0.075 \%$ ammonium persulfate, and $10 \mu \mathrm{L}$ TEMED) in $100 \mathrm{mM}$ sodium phosphate buffer, $\mathrm{pH} 7.0$, is added, followed by insertion of a 15 well comb. The electrophoresis apparatus is assembled, and $100 \mathrm{mM}$ sodium phosphate buffer, $\mathrm{pH} 6.0$, is used in the upper and lower chambers as running buffer. Samples are prepared by combining equal volumes of sample and loading buffer (1 $\mathrm{M}$ acetic acid, $6 \mathrm{M}$ urea, $5 \%$ sucrose, and cytochrome $\mathrm{C}$ for color), and the current is applied to the loaded gels after reversing the anode and cathode leads. To prevent damage to the electrophoresis apparatus, it is important to ascertain whether the anode and cathode materials are compatible with reverse-polarity PAGE; platinum wire electrodes were used for all reverse-polarity PAGE experiments described. Samples are subjected to electrophoresis at $20 \mathrm{~mA}$ for the first $3 \mathrm{~h}$. Once the positively charged peptides have moved into the resolving portion of the gel, the current can be increased to $40 \mathrm{~mA}$ without compromising peptide resolution. To reduce the effects of heat generated during electrophoresis, it is helpful to limit the voltage and/or current to $200 \mathrm{~V}$ and $40 \mathrm{~mA}$, respectively, and to run the gels at $4^{\circ} \mathrm{C}$. We also recommend that the buffer in the upper and lower reservoirs be changed every $6-8$ $h$. The typical run time for the reversepolarity PAGE performed in this report was approximately $18 \mathrm{~h}$. However, the run time will vary with the properties of individual peptides and must be established empirically.

To optimize this technique, we chose to analyze peptides representing the DNA binding domains from the basic leucine zipper transcription factors, BATF ( ${ }^{36}$ NRIAAQKSRQRQ ${ }^{47}$ ) and 